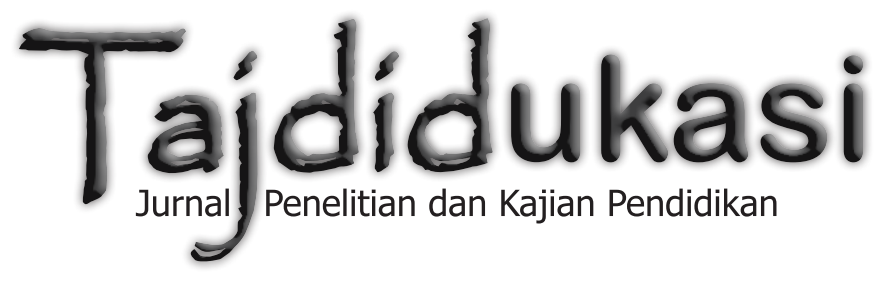




\section{Tajdidukasi}

Volume VIII, No. 1, Januari 2018

ISSN: 1979-6943

Tajdidukasi: Jurnal Penelitian dan Kajian Pendidikan merupakan jurnal Penelitian dan Kajian Pendidikan yang berisi Penelitian Tindakan Kelas (PTK) dan Penelitian Tindakan Sekolah (PTS) serta Kajian Pendidikan interdisipliner di Perguruan Tinggi yang diterbitkan Majelis Pendidikan Dasar dan Menengah Pimpinan Wilayah Muhammadiyah Daerah Istimewa Yogyakarta. Artikel hasil PTK dan PTS serta kajian pemikiran pendidikan ditulis oleh para Guru dan Kepala Sekolah serta Dosen dalam mengujicobakan metode dan strategi pembelajaran untuk meningkatkan kualitas pendidikan baik SD/MI, SMP/MTs dan SMA/MA/SMK serta Perguruan Tinggi. Artikel PTK dan PTS fokus pada mata pelajaran di sekolah/madrasah, seperti Ilmu Pengetahuan Alam (IPA), Imu Pengetahuan Sosial (IPS), Matematika, Fisika, Kimia, bahkan teknik, seperti Teknik Mesin, Elektro, Informatika dan lain sebagainya. Sementara itu, artikel Kajian Pendidikan merupakan penelitian interdisipliner dan multidisipliner yang dilakukan Dosen di Perguruan Tinggi terhadap khasanah keIslaman.

Tajdidukasi: Jurnal Penelitian dan Kajian Pendidikan adalah jurnal terbuka yang versi softfile-nya bisa dibaca dan diakses secara gratis, sementara versi print out/ hardcopy dapat diperoleh dengan menghubungi distributor di alamat serial tajdidukasi.ac.id. Sof-file keseluruhan artikel yang diterbitkan dapat diakses melalui Tajdidukasi Open Access Juornal di www.dikdasmenpwmdiy.or.id

\section{Pimpinan Editor \\ Suyadi, Universitas Ahmad Dahlan (UAD) Yogyakarta, Indonesia}

\section{Anggota Editor}

Arif Budi Raharjo, Universitas Muhammadiyah Yogyakarta (UMY), Indonesia

Achmad Muhammad, UIN Sunan Kalijaga Yogyakarta, Indonesia

Hendro Widodo, Universitas Ahmad Dahlan (UAD) Yogyakarta

Mundzirin Yusuf, UIN Sunan Kalijaga Yogyakarta, Indonesia

Sumedi, UIN Sunan Kalijaga Yogyakarta, Indonesia

Sukamto, Universitas Muhammadiyah Yogyakarta (UMY), Indonesia

Sumarsono, UIN Sunan Kalijaga Yogyakarta Indonesia

Sarjilah (Lembaga Penjaminan Mutu Pendidikan) Yogyakarta

Fathur Rahman, M.Si., Universitas Negeri Yogyakarta (UNY) Indonesia

\section{Editor Pelaksana}

Suryanto, Universitas Muhammadiyah Yogyakarta (UMY), Indonesia

Suyatno, Universitas Ahmad Dahlan (UAD) Yogyakarta

Farid Setiawan, Universitas Ahmad Dahlan (UAD) Yogyakarta

Alamat Redaksi:

Kantor Majelis Pendidikan Dasar dan Menengah Pimpinan

Wilayah Muhammadiyah D.I. Yogyakarta

Jl. Gedongkuning No. 130B Yogyakarta

Kode Pos : 55171

Telephone : (0274) 377078

Facsimile : (0274) 371718

Website : www.dikdasmenpwmdiy.or.id

E-Mail : tajdidukasi@dikdasmenpwmdiy.or.id 


\title{
PENDEKATAN BRAIN BASED LEARNING SEBAGAI BASIS PEMBELAJARAN DALAM KURIKULUM 2013
}

\author{
Hendro Widodo \\ Universitas Ahmad Dahlan, Yogyakarta \\ hwmpaiuad@gmail.com
}

\begin{abstract}
Abstrak
Artikel ini bertujuan untuk mendeskripsikan pendekatan braind based learning sebagai basis pembelajaran dalam kurikulum 2013. Keberhasilan pembelajaran dalam arti tercapainya standar kompetensi, sangat bergantung pada kemampuan guru mengolah pembelajaran yang dapat menciptakan situasi yang memungkinkan peserta didik belajar. Pendekatan pembelajaran BBL sejalan dengan konseptual pendidikan holistik. Hal ini dadasari oleh pemikiran bahwa setiap peserta didik memiliki potensi yang berbeda dan itu merupakan fitrah manusia. Potensi yang dimiliki peserta didik dikembangkan lewat proses pendidikan sehingga mendistorsi makna pendiidkan bila proses pendidikan mengabaikan salah satu potensi tersebut. Hal ini pulalah yang dikembangkan dalam kurikulum 2013, bahwa orientasi pencapaian kompetensi peserta didik di arahkan pada pencapaian kompetensi holistik yaitu dari kompetensi sikap spiritual dan sosial, kompetensi pengetahuan dan kompetensi ketermapilan/psikomotorik.
\end{abstract}

Kata Kunci: Pendekatan Brain Based Learning, Pembelajaran, Kurikulum 2013

\section{A. Pendahuluan}

Sekolah sebagai jalur pendidikan formal sampai sekarang dipandang masih menjadi tumpuan untuk mewujudkan tujuan pendidikan. Tujuan pendidikan nasional sebagaimana termaktub di dalam pasal 3 UndangUndang Nomor 20 Tahun 2003 bahwa tujuan pendidikan nasional adalah berkembangnya potensi peserta didik agar menjadi manusia yang beriman dan bertakwa kepada Tuhan Yang Maha Esa, berakhlak mulia, sehat, berilmu, cakap, kreatif, mandiri dan menjadi warga negara yang demokratis dan bertanggung jawab. Berdasarkan rumusan ini tampak bahwa tujuan pendidikan adalah mengusahakan agar peserta didik menjadi orang yang baik dan cerdas. Dengan kata lain, tujuan pendidikan nasional sebenarnya mengarah pada pencapaian nilai-nilai yang bersifat holistik.

Pencapaian nilai-nilai yang bersifta holistik tersebut haruslah didukung oleh pembelajaran secara konstruktivis yang didasari oleh pemikiran bahwa setiap 
individu peserta didik merupakan bibit potensial yang mampu berkembang secara mandiri. Tugas pendidikan adalah memotivasi agar setiap peserta didik mengenali potensinya sedini mungkin dan menyediakan pelayanan yang sesuai dengan potensi yang dimiliki serta mengarahkan pada persiapan menghadapi tantangan ke depan. Pendidikan mengarah pada pembentukan nilai dalam bentuk konkrit yang berkembang dalam tiga ranah kemampuan, yaitu: kognitif, psikomotor, dan afektif.

Taksonomi pendidikan sebagai bingkai wilayah kepribadian manusia yakni membentuk sikap (affective domain), mengembangkan pengetahuan (cognitive domain), serta melatihkan keterampilan (psychomotoric domain), nampaknya belum menjadi domain yang utuh dalam tataran outcomes pendidikan. Bahkan dalam praktiknya, domain kognitif lebih dipentingkan dari pada domain yang lainnya. Seolah kepribadian manusia hanya berhubungan dengan kecerdasan otaknya, yang belakangan dikenal dengan IQ. Padahal seseorang dengan IQ tinggi tidak menjamin mampu mengatasi berbagai masalah yang dihadapi, kecuali ia juga memiliki piranti kecerdasan lainnya yang tinggi (Ahmad Najib Burhani, 2001: 156).

Imam Suprayogo (2012:233) menegaskan bahwa pendidikan selama ini baru mampu mengembangkan aspek intelektual, namun belum memperhatikan aspek lainnya. Pendidikan selama ini hanya mengedepankan aspek kognitif, dan kurang mampu mengembangkan aspek psikomotorik dan afektif. Pendidikan baru berhasil mengantarkan generasi muda menjadi cerdas, tetapi belum berkarakter sebagaimana diharapkan. Hal senada dikemukakan oleh Jalaluddin (2012: 89) bahwa tujuan pendidikan diarahkan untuk mencetak anak pandai secara kognitif (yang menekankan pengembangan otak kiri saja dan hanya meliputi aspek bahasa dan logis-matematis), maka banyak materi pelajaran yang berkaitan dengan pengembangan otak kanan (seperti kesenian, musik, imajinasi, dan pembentukan karakter) kurang mendapatkan perhatian. Kalaupun ada, maka orientasinya pun lebih kepada kognitif (hafalan), tidak ada apresiasi dan penghayatan yang dapat menumbuhkan kegairahan untuk belajar dan mendalami materi lebih lanjut. Mata pelajaran yang bersifat subject matter juga makin merumitkan permasalahan, karena para siswa tidak melihat bagaimana keterkaitan antara satu mata pelajaran dengan yang lainnya, serta tidak relevan dengan kehidupan nyata. Akibatnya, para siswa tidak mengerti manfaat dari materi yang dipelajarinya untuk kehidupan nyata. Sistem pendidikan seperti ini membuat manusia berpikir secara parsial, terkotak-kotak atau tidak holistik.

Realitas di atas harus dipahami oleh para penyelenggara pendidikan, khususnya guru yang secara intensif melakukan kegiatan pembelajaran di kelas. Hal yang harus diperhatikan dalam pembelajaran adalah karakteristik 
peserta didik dan perbedaan daya penerimaan yang dimilikinya, mengingat antara peserta didik satu dengan yang lain tentunya memiliki karakteristik dan daya penerimaan yang berbeda. Keberhasilan pembelajaran dalam arti tercapainya standar kompetensi, sangat bergantung pada kemampuan guru mengolah pembelajaran yang dapat menciptakan situasi yang memungkinkan peserta didik belajar. Melalui pendekatan Brain-Based Teaching diharapkan guru dapat memunculkan kondisi pembelajaran yang optimal. Penerapan pembelajaran yang berbasis otak (brain based learning) bertujuan mengembalikan proses pembelajaran kepada hakikatnya, yaitu pembelajaran yang sesuai dengan cara otak bekerja. Pendekatan pembelajaran ini menawarkan sebuah konsep untuk menciptakan pembelajaran dengan berorientasi pada upaya pemberdayaan potensi otak siswa. Di sini peran utama guru adalah memahami riset otak secukupnya untuk membantu siswa berkembang sesuai potensinya masing-masing.

\section{B. Pembahasan}

1. Pendekatan Brain-Based Teaching (BBL)

Menurut Jensen (2011:6) BrainBased Learning merupakan suatu model yang mempertimbangkan bagaimana otak belajar dengan optimal. Optimalisasi yang dimaksud bukan dengan memaksakan otak untuk menerima pembelajaran sebanyak-banyaknya, namun membiarkan otak belajar dan bekerja sesuai dengan ritmenya. Hal senada dikemukakan oleh Duman (2006) bahwa Brain-Based Learning adalah pembelajaran yang berpusat pada siswa (student centered) yang menggunakan seluruh bagian otak dan mengakui bahwa tidak semua siswa belajar dengan cara yang sama. Brain Based Learning juga merupakan proses aktif dimana siswa berperan secara aktif membangun pengetahuannya sendiri terhadap situasi pembelajaran yang beragam

Pendekatan Brain-Based Learning adalah konsep belajar yang memanfaatkan satu kesatuan lima sistem pembelajaran alamiah otak, yaitu emosi, sosial, kognisi, fisik dan reflektif, dan memberikan porsi yang seimbang terhadap penggunaan kelima sistem pembelajaran tersebut tanpa mengunggulkan salah satu sistem (Given, 2007:389). Definisi mengandung makan bahwa pendekatan ini bertujuan untuk mengembangkan lima sistem pembelajaran alamiah otak yang dapat mengembangkan potensi otak dengan maksimal. Kelima sistem pembelajran tersebut adalah sistem pembelajaran emosional, sosial, kognitif, fisik, dan reflektif. Kelima sistem pembelajaran tersebut saling mempengaruhi dan tidak dapat berdiri sendiri.

Keterlibatan emosi pada pembelajaran sebagai pedagogi pendidikan merupakan bagian dari upaya membimbing anak mencapai tujuan pendidikan yang akan sangat berkaitan dengan fungsi otak. Atau dengan kata lain pengendalian dan perangsangan emosial pada 
peserta didik ke arah yang lebih baik merupakan tugas dari suatu proses pembelajaran. Pasiak (2005: 98) mengungkapkan bahwa system limbic bersama dengan komponen amyglada yang terdapat pada otak memegang peranan penting dalam pengaturan emosi. Otak akan merekam kejadian melalui sirkuit khusus dalam otak dan menyimpannya sehingga ketika suatu saat si pemilik otak tersebut ingin membayangkannya maka otak akan bereaksi seperti kejadian sesungguhnya.

Berdasarkan definisi di atas maka dapat disimpulkan bahwa pendekatan brain based learning merupakan pendekatan pembelajaran komperehensif/ metakognisi berorientasi pada upaya pemberdayaan potensi otak siswa yang memaksimalkan potensi emosi, sosial, kognitif, fisik, dan kemampuan reflektif setiap peserta didik. Kelima aspek tersebut merupakan aspek- aspek yang tidak dapat diabaikan satu sama lain. Dalam pembelajaran, aspek- aspek tersebut haruslah mendapat perhatian dengan porsi yang seimbang.

2. Desain pembelajaran Brain Based

\section{Learning}

Jensen (2008: 484: 490) menyatakan tujuh tahap garis besar perencanaan pembelajaran berbasis brain based learning, sebagai berikut:

a. Pra-pemaparan

Fase ini memberikan sebuah ulasan kepada otak tentang pembelajaran baru sebelum benar-benar menggali lebih jauh: pra-pemaparan membantu otak membangun peta konseptual yang lebih baik.

\section{b. Persiapan}

Tahap ini merupakan fase dalam menciptakan keingintahuan atau kesenangan siswa terhadap materi yang akan diajarkan.

c. Inisiasi dan Akuisisi

Guru memberikan proyek yang memfasilitasi siswa untuk membangun

pengetahuan dan pemahaman awal tentang suatu materi pelajaran berdasarkan pengalaman belajar yang mereka alami sendiri.

d. Elaborasi

Hal ini merupakan tahap pemrosesan informasi. Tahap ini membutuhkan kemampuan berpikir yang murni dari pihak pembelajar.

e. Inkubasi dan Memasukkan Memori

Fase ini menekankan pentingnya waktu istirahat dan waktu untuk mengulang kembali.

\section{f. Verifikasi dan Pengecekan Keyaki-} nan

Fase ini bukan hanya untuk kepentingan guru, para pembelajar juga perlu mengonfirmasikan pembelajaran mereka untuk diri mereka sendiri.

\section{g. Perayaan dan Integrasi}

Fase ini penting untuk melibatkan emosi siswa dengan baik. Guru dapat membuat fase ini mengasyikkan, ceria dan menyenangkan.

Ada tiga strategi utama yang dapat dikembangkan dalam pembelajaran dengan pendekatan brain based 
learning ini (Sapa'at, dalam Rahmi Syarwan, dkk, 2014: 30), yakni: (1) menciptakan lingkungan belajar yang menantang kemampuan berpikir siswa; (2) menciptakan lingkungan pembelajaran yang menyenangkan; dan (3) menciptakan situasi pembelajaran yang aktif dan bermakna bagi siswa. Ketiga hal tersebut mampu membantu siswa dalam mengembangkan kemampuan penalaran matematis. Lingkungan pembelajaran yang menyanangkan akan memberikan motivasi pada siswa untuk menyampaikan ide-ide mengenai materi yang sedang dipelajari. Pembelajaran yang aktif mampu mengasah kemampuan siswa dalam menganalisa suatu permasalahan, mencari solusi yang tepat dan mampu memberikan alasan terhadap solusi yang diberikan.

Ketiga strategi dalam pendekatan brain based learning dijelaskan Ozden \& Gultekin (2008: 16) sebagai berikut: Fase orchestrated immersion difokuskan untuk membuat pokok bahasan dalam pembelajaran menjadi lebih bermakna dan bertahan dalam ingatan siswa. Fase ini membantu siswa membuat pola dan berasosiasi dengan otak mereka masing-masing saat mereka diberikan permasalahan yang kaya pengalaman belajar, sehingga pembelajaran yang didapat akan lebih bertahan dalam memori siswa. Untuk fase relaxed alertness, siswa ditantang untuk memecahkan suatu permasalahan dengan baik tetapi meminimalisasi ancaman yang didapat jika ia tidak dapat melakukan yang terbaik, karena hasil belajar menjadi lebih tinggi ketika seseorang dalam keadaan nyaman tanpa ancaman Fase active processing dilakukan dengan membentuk kelompok belajar yang memfasilitasi siswa agar siswa mampu menyerap informasi dengan baik, tetapi siswa harus tetap diberikan penghargaan walaupun hasil kinerjanya belum maksimal.

Pada pendekatam Brain Based Learning menuntut peserta didik untuk lebih aktif dalam pembelajaran karena siswa diberikan kendali untuk mengelola pembelajrannya secara mandiri. Siswa dituntut untuk mampu mengidentifikasi berbagai masalah yang perlu dipelajari lebih jauh (investigation), tahu di mana harus mencari sumber-sumber belajar yang berkaitan dengan masalah tadi, mampu menentukan prioritas dan merancang penelusuran sumber belajar, mampu mempelajari materi yang ada di dalam sumber belajar tadi, dan kemudian menghubungkan informasi yang telah terkumpul dengan topik bahasan yang sedang dipelajarinya. Selain itu, pembelajaran dengan pendekatan pembelajaran BBL (Brain Based Learning) sebagai pembelajaran yang berpusat pada peserta didik (I Gusti Agus Made Mustiada, 2014:8).

3. Keunggulan dan Kekurangan Pendekatan (Brain Based Learning)

Menurut Nyoman Kusmariyatni (2012: 176-177) pendekatan pembelajaran ini memiliki beberapa keunggulan sebagai berikut. Pertama, melalui penerapan model $\mathrm{BBL}$, siswa merasakan 
terlibat penuh dalam kegiatan belajar sehingga proses belajar menyenangkan. Hal ini menyebabkan siswa termotivasi untuk belajar. Kedua, guru dapat menempatkan peranannya sebagai fasilitator dan mediator dalam pembelajaran di kelas secara lebih optimal. Ketiga, implementasi model BBL memberikan peluang bagi guru untuk melaksanakan penilaian secara objektif pada siswa melalui observasi. Melalui rubrik penilaian yang digunakan guru dapat menghindari unsur subjektivitas dalam penilaian. Keempat, adanya integrasi yang berkesinambungan antara pembelajaran dengan penilaian. Kelima, implementasi model BBL dapat membelajarkan siswa untuk lebih aktif dan mampu merefleksikan kegiatan belajar sehingga pikiran siswa sepenuhnya pada proses belajar yang berlangsung. Keenam, melalui implementasi model BBL, kegiatan pembelajaran menjadi lebih terarah dan sistematis serta dapat memfokuskan perhatian siswa dalam pembelajaran. Ketujuh, model BBL memberikan kesempatan kepada siswa untuk belajar sesuai dengan apa yang dikehendaki siswa melalui penggalian pengalaman yang dimiliki oleh siswa dan memanfaatkan pengalaman tersebut sebagai informasi awal untuk melaksanakan pembelajaran lebih lanjut. Kedelapan, model BBL memberikan kesempatan kepada siswa belajar sesuai dengan kemampuannya, bagaimana menggunakan sebuah proses interaktif untuk menilai apa yang mereka ketahui, mengidentifikasi apa yang mereka ingin ketahui, dan mengevaluasi apa yang bisa dilaksanakan oleh siswa. Kesembilan, model BBL memberikan kesempatan kepada siswa untuk terlibat aktif dalam proses pembelajaran, berinteraksi, baik terhadap materi, teman, maupun guru. Terakhir, implementasi model BBL memberikan rasa nyaman kepada siswa ketika siswa kurang berani bertanya secara langsung sehingga siswa dapat menuliskan permasalahan mereka pada lembar refleksi.

Begitu pula kegiatan otak yang terkait dengan memori juga telah dibuktikan dari penelitian yang dilakukan oleh Chatib (2011: 137) dimana pada umumnya peserta didik akan lebih kuat dan lama mengingat materi pelajaran melalui praktik langsung. Dari 100 orang pendidik berusia 30 tahunan yang diminta menuliskan kejadian menarik yang masih diingat pada saat masih duduk di bangku SD menunjukkan hampir $90 \%$ proses pembelajaran yang masih terus mereka ingat adalah proses pembelajaran melalui modalitas kinestetis atau melalui aktivitas sedangkan model berceramah sangat jarang diingat. Beliau juga mengungkapkan bahwa pengalaman memiliki muatan emosi yang kuat. Melalui pembelajaran dengan melibatkan aktivitas peserta didik, baik aktivitas fisik maupun mental akan lebih mudah terekam oleh ingatan dan memori otak sehingga pengalaman pembelajaran akan lebih bermakna.

Di samping itu, Christianti (2007: 4) menyatakan pengembangan emosional anak juga dapat diimplementasikan melalui kegiatan bermain dimana me- 
lalui permainan dapat membangkitkan berbagai rasa seperti rasa memiliki, rasa diterima dalam suatu kelompok, rasa untuk belajar hidup berkelompok dan bekerja sama dalam berbagai perbedaan, serta rasa untuk selalu menyesuaikan tingkah laku terhadap anak-anak yang lain. Hal inilah yang kemudian dapat membangkitkan nilai-nilai yang sangat bermanfaat bagi kehidupan mereka nantinya seperti penguasaan diri dan ego serta pengaturan emosi. Begitu pula Khasanah, Prasetyo, \& Rakhmawati (2011: 94) menambahkan bahwa melalui permainan akan mendorong kekreativitasan anak yang dimulai dari perkembangan emosionalnya. Melalui kondisional permainan ini pula, anak terlibat dalam kegiatan pembelajaran, terjadi interaksi antar peserta didik dan peserta didik dengan guru sehingga pengalaman belajar yang diterimak peserta didik akan lebih berkesan dalam memeroi otaknya.

Munawaroh \& Haryanto (2005: 121) mengungkapkan bahwa proses pembelajaran yang berdasarkan pada sistem kerja otak pada dasarnya merupakan usaha untuk menyimpan materi yang dipelajari ke dalam memori jangka panjang dengan informasi yang masuk akal dan memiliki makna. Karenanya keterlibatan pengalaman dan emosi dalam penyampaian suatu materi di dalam kelas sangat diperlukan. Artinya kerja otak dan emosi merupakan kesatuan sistem yang saling menguatkan dalam memperoleh pengalaman belajaran yang bermakna.
Sedangkan kendala atau kekurangan yang ditemui selama proses pembelajaran menggunakan pendekatan atau model pembelajaran BBL adalah sebagai berikut: pertama, guru mengalami kesulitan dalam memberikan bimbingan secara merata kepada siswa mengingat keterbatasan waktu mengajar; kedua, beberapa siswa belum terbiasa melaksanakan praktikum, aktif bertanya, menyampaikan pendapat, dan berdiskusi dengan teman sekelasnya; dan ketiga beberapa materi agak sulit dicarikan konteksnya. Berdasarkan hal tersebut guru dituntut untuk lebih kreatif mencari konteks dalam kehidupan sehari-hari yang relevan dengan materi yang dikaji.

Pendekatan pembelajaran BBL sejalan dengan konseptual pendidikan holistik. Hal ini dadasari oleh pemikiran bahwa setiap peserta didik memiliki potensi yang berbeda dan itu merupakan fitrah manusia. Potensi yang dimiliki peserta didik dikembangkan lewat proses pendidikan sehingga mendistorsi makna pendiidkan bila proses pendidikan mengabaikan salah satu potensi tersebut. Hal ini pulalah yang dikembangkan dalam kurikulum 2013, bahwa orientasi pencapaian kompetensi peserta didik di arahkan pada pencapaian kompetensi holistik yaitu dari kompetensi sikap spiritual dan sosial, kompetensi pengetahuan dan kompetensi ketermapilan/psikomotorik. 


\section{Penutup}

Pendekatan Brain-Based Teaching merupakan salah satu bentuk pembelajaran yang dapat digunakan dalam pembelajaran yang lebih bermakna. Pendekatan Brain-Based Teaching merupakan konsep belajar yang memberdayakan secara holistik dari kelima sistem otak, yaitu emosi, sosial, kognisi, fisik dan reflektif, dan memberikan porsi yang seimbang terhadap penggunaan kelima sistem pembelajaran tersebut tanpa mengunggulkan salah satu sistem.

Spirit pendekatan Brain-Based Teaching ini merupakan spirit dalam pendidikan holistik yaitu pendidikan yang mengembangkan seluruh potensi peserta didik secara harmonis (terpadu dan seimbang) sehingga menuntut adanya keterpaduan yang komprehensif antara yaitu emosi, sosial, kognisi, fisik dan reflektif, dalam pembelajaran. Prinsip keterpaduan dan seimbang ini menempatkan potensi kemanusiaan dikembangkan dalam proses pembelajaran. Spirit ini pulalah yang dikembangkan dalam kurikulum 2013, yaitu ketercapain potensi peserta didik pada kemampuan kognitif, afektif dan psikomotorik yang terpadu dalam pembelajaran.

\section{DAFTAR PUSTAKA}

Chatib, M. 2001. Sekolahnya Manusia: Sekolah Berbasis Multiple Intelligences di Indonesia. Bandung: Mizan.

Christianti, M. 2007. Anak dan Bermain. Makalah Disajikan Dalam
Jurnal Club Prodi PGTK UNY Dan Majalah EduTOT PGTK $U N Y$. Retrieved from http://staff. uny.ac.id/sites/default/files/penelitian/Martha Christianti, M.Pd./ Anak Dan Bermain.pdf

Depdikbud. 1998. Kamus Besar Bahasa Indonesia. Jakarta: Balai Pustaka.

Duman, B. 2006. "The Effect of BrainBased Instruction to Improve on Students'

Academic Achievement in Social Studies".9th International Conference on Engineering Education, 23-28 July 2006 in San Juan. (Online), (http://www.icee.usm. edu/icee/conferences/icee2006/ papers/33 80 .pdf.

Given, B.K. 2007. Brain Based Teaching (Merancang Kegiatan BelajarMengajar yang Melibatkan Otak, Emosional, Sosial Kognitif, Kinestetis, dan Reflektif). Bandung: Kaifa.

I Gusti Agus Made Mustiada, 2014 Pengaruh Model Pembelajaran BBL (Brain Based Learning) Bermuatan Karakter Terhadap Hasil Belajar IPA. Jurnal Mimbar PGSD Universitas Pendidikan Ganesha Jurusan PGSD Vol: 2 No: 1 Tahun 2014.

Khasanah, I., Prasetyo, A., \& Rakhmawati, E. (2011). Permainan Tradisional Sebagai Media Stimulasi Aspek Perkembangan Anak Usia Dini. Jurnal Penelitian PAUDIA, 


$$
1(1), 91-105 .
$$

Kusmariyatni Nyoman. 2012. Model Brain Based Learning Dan Hasil Belajar Ipa Siswa Sekolah Dasar. Jurnal Pendidikan dan Pengajaran, Jilid 46, Nomor 2, Juli 2012, hlm.165-173

Jalaludin, 2012. "Membangun SDM Bangsa Melalui Pendidikan Karakter", Jurnal Penelitian Pendidikan, Vol. 13, No. 2, Oktober 2012

Jensen, E. 2008. Brain-Based Learning Pembelajaran Berbasis Kemampuan Otak Cara Baru dalam Pengajaran dan Pelatihan Edisi Revisi. Yogyakarta: Pustaka Belajar

Jensen, E. 2011. Brain-Based Learning Pembelajaran Berbasis Otak. Jakarta: Indeks

Munawaroh, I., \& Haryanto. 2005. Neurosience dalam pembelajaran. Majalah Ilmiah Pembelajaran, Vol .I, No 1 Mei 2005

Najib, Ahmad Burhani. 2001. Menggugat Peran Agama Membongkar Doktrin yang Membatu, Jakarta: Kompas

Ozden, M. \& Gultekin, M. 2008. The effects of brain-based learning on academic achievement and retention of knowledge in science course, Electronic Journal of Science Education. 12(1), 1-16.
Pasiak, T. 2005. Revolusi IQ/EQ/SQ: Antara Neurosains dan Al-Quran (V). Bandung: Mizan.

Rukiyati, 2013. "Urgensi Pendidikan Karakter Holistik Komprehensif Di Indonesia", Jurnal Pendidikan Karakter, Tahun III, Nomor 2, Juni 2013.

Supratiknya, A. (ed.), 1993. Psikologi Kepribadian 2: Teori-Teori Holistik (Organismik Fenomenologis), Yogyakarta: Kanisius.

Suprayogo, Imam. 2012. "Pendidikan Holistik dalam Perspektif Islam", dalam Abd. Rahman A. Ghani dan Sugeng Riadi (ed), Pendidikan Holistik, Konsep dan implementasi dalam Pendidikan, Jakarta: Uhamka Press.

Rahmi, Syarwan. 2014. Pengaruh Pendekatan Brain Based Learning (BBL) Terhadap Kemampuan Penalaran Matematis Siswa Kelas VII SMP Islam Raudhatul Jannah Payakumbuh. Vol. 3 No. 1 (2014) Jurnal Pendidikan Matematika : Part 2 Hal 29- 34. 